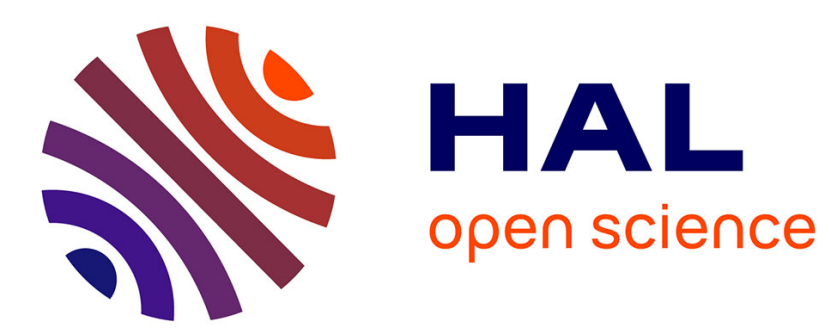

\title{
A spatial mismatch between invader impacts and research publications
}

\author{
Céline A Bellard, J.M. M Jeschke
}

\section{To cite this version:}

Céline A Bellard, J.M. M Jeschke. A spatial mismatch between invader impacts and research publications. Conservation Biology, 2016, 30 (1), pp.230-232. 10.1111/cobi.12611 . hal-03248762

\section{HAL Id: hal-03248762 \\ https://hal.science/hal-03248762}

Submitted on 3 Jun 2021

HAL is a multi-disciplinary open access archive for the deposit and dissemination of scientific research documents, whether they are published or not. The documents may come from teaching and research institutions in France or abroad, or from public or private research centers.
L'archive ouverte pluridisciplinaire HAL, est destinée au dépôt et à la diffusion de documents scientifiques de niveau recherche, publiés ou non, émanant des établissements d'enseignement et de recherche français ou étrangers, des laboratoires publics ou privés. 


\title{
A spatial mismatch between invader impacts and research publications
}

\author{
C. Bellard* and J.M. Jeschke†t \\ *Department of Genetics, Evolution and Environment, Center for Biodiversity and Environment Research, University College of \\ London, London, U.K., email c.bellard@ucl.ac.uk \\ $\nmid$ Leibniz-Institute of Freshwater Ecology and Inland Fisheries (IGB), Müggelseedamm 310, 12587 Berlin, Germany \\ †Department of Biology, Chemistry, Pharmacy, Institute of Biology, Freie Universität Berlin, Königin-Luise-Strasse 1-3, 14195 Berlin, \\ Germany
}

Geographic research biases are widespread in conservation biology and ecology. Although most researchers would probably agree with this statement, there are relatively few studies on geographic biases (but see Martin et al. 2012), and the management implications of this bias are rarely discussed. We sought to shed some light on this issue through a consideration of biological invasions, where research has increased rapidly during recent decades.

Pyšek et al. (2008) raised concerns that the understanding of biological invasions is geographically biased and that these biases may cause knowledge gaps that limit the capacity to mitigate detrimental impacts caused by invaders. Pyšek et al. (2008) and later Lowry et al. (2012) highlight that some locations have intensively been studied (e.g., Europe) but others less so (e.g., tropical areas). They recommend that future research on biological invasions be primarily in these understudied regions. However, invasive non-native species (INS) and their impacts are not evenly distributed geographically; hence, it is possible that geographic biases in publications simply reflect geographic biases in invader impacts.

We address this question by focusing on invader impacts on threatened species. We combined the results of Lowry et al. (2012) and data from the International Union for Conservation of Nature (IUCN) Red List on the spatial distribution of 1282 vertebrates (birds, mammals, amphibians, and reptiles) threatened (i.e., vulnerable, endangered, or critically endangered) by INS (Supporting Information). We then built a cartogram with country size according to the number of INS-threatened species and with the country colors indicating whether there is a research deficit (Fig. 1). For the latter, we calculated the difference between the percentage of studies con- ducted in a country (studies from Lowry et al. 2012) and the percentage of INS-threatened species in that country (Supporting Information).

North America, Western Europe, New Zealand, and South Africa had relatively many research publications compared with the number of species threatened by invaders in these countries (Fig. 1). Australia had both a high research output and a large number of INSthreatened species $(n=108)$. Central and South American countries appeared to have a strong research deficit: there were relatively few international publications on invader impacts, but there were many INS-threatened species. Specifically, Mexico ( $n=129$ INS-threatened species), Ecuador, Colombia, Peru, and Argentina were among the 10 countries with the most INS-threatened species. A caveat, particularly for Spanish-speaking countries, is that Lowry et al.'s data include only English publications; thus, they underestimate total publication output. This caveat does not apply equally to Madagascar, India, and Oceanic islands, where strong research deficits were found as well. For the latter, this was consistent with the spatial distribution of data-deficient species among the IUCN Red List species threatened by INS (especially for birds [Supporting Information]). Most African countries ranked similarly for research publications and number of INS-threatened species, which were both relatively low (except for Madagascar and South Africa, where there are many INS-threatened species). These low values are attributable to either an actual low impact of invasions (and associated low naturalized number of species, Pyšek et al. 2008) or to low research intensity.

In most countries, research output and number of INS-threatened species differed. We observed a strong research deficit where INS impact was high and biodiversity was rich and threatened (i.e., where conservation measures are particularly needed and valuable). The 


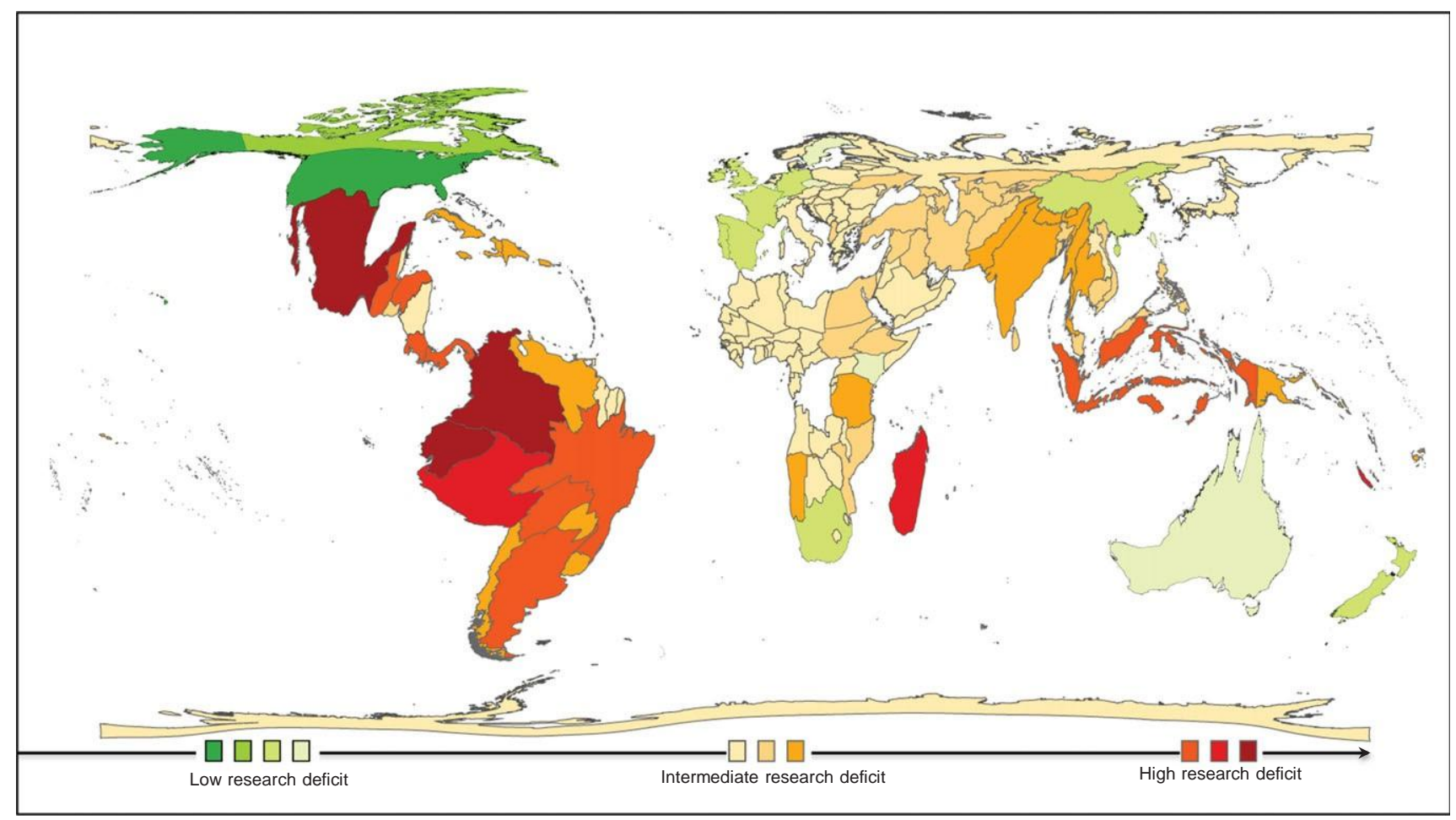

Figure 1. Cartogram showing deficits in research on biological invasions by country. The size of each country represents the number of native vertebrates threatened by invaders in that country (INS-threatened vertebrates) (red, few publications relative to the number of INS-threatened vertebrates in the country [high research deficit]; green, more publications relative to the number of INS-threatened vertebrates in the countries [low research deficit]).

spatial pattern of large numbers of publications was strongly associated with the financial resources available per country, whatever the actual impact of INS. Most knowledge on biological invasions corresponds to hotspots of introduced non-native species, translocated due to economic activities (Seebens et al. 2013), rather than to impacts of INS. Although such a pattern has been highlighted in a few other conservation studies (Martin et al. 2012), it is particularly pronounced for INS, for example, in South American countries that are well represented in conservation studies.

These geographic research biases have at least 3 critical management implications. First, managers tend to extrapolate and interpret results in a broader context, yet invader impacts are context-dependent (Kueffer et al. 2013). Thus, it is unclear whether research results for one ecosystem will translate to another ecosystem. Second, because INS do not have political boundaries, the lack of knowledge in some highly vulnerable regions may result in a delay to control invasions at an early stage. Third, for reaching Aichi Target 9 of the Convention on Biological Diversity by 2020, a global overview of invader impact that is not biased by research deficits is needed.

Our results highlight the need for more research in areas with a current deficit (e.g., Madagascar, India, and
Oceanic islands). This could be achieved, at least partly, by joint research programs between wealthy countries and those with fewer financial resources. Otherwise, biodiversity may be lost due to an unfortunate mismatch between invader impacts and research activity.

\section{Acknowledgments}

We thank G. Mace for comments. C.B. was supported by an AXA fellowship and J.M.J. by the DFG project JE 288/9-1 and the ERA-Net BiodivERsA project FFII (national funder DFG, JE 288/7-1). We also thank the editor and the three reviewers for their valuable comments.

\section{Supporting Information}

Extended information on methods (Appendix S1), the number of studies in Lowry et al. (2012) and the number of INS-threatened species (Appendix S2), and the spatial distribution of data-deficient INS-threatened species (Appendix S3) are available online. The authors are solely responsible for the content and functionality of these materials. Queries (other than absence of the material) should be directed to the corresponding author. 


\section{Literature Cited}

Kueffer C, Pyšek P, Richardson DM. 2013. Integrative invasion science: model systems, multi-site studies, focused meta-analysis and invasion syndromes. The New Phytologist 200:615-633.

Lowry E, Rollinson EJ, Laybourn AJ, Scott TE, Aiello-Lammens ME, Gray SM, Mickley J, Gurevitch J. 2012. Biological invasions: a field synopsis, systematic review, and database of the literature. Ecology and Evolution 3:182-196.
Martin LJ, Blossey B, Ellis E. 2012. Mapping where ecologists work: biases in the global distribution of terrestrial ecological observations. Frontiers in Ecology and the Environment 10:195-201.

Pyšek P, Richardson DM, Pergl J, Jarošik V, Sixtová Z, Weber E. 2008. Geographical and taxonomic biases in invasion ecology. Trends in Ecology \& Evolution 23:237-244.

Seebens H, Gastner MT, Blasius B. 2013. The risk of marine bioinvasion caused by global shipping. Ecology Letters 16:782-790. 